\title{
Article \\ Assessing Ecosystem Condition: Use and Customization of the Vegetation Departure Metric
}

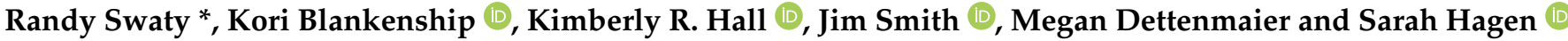 \\ North America Science-LANDFIRE, The Nature Conservancy, Arlington, VA 22203, USA; \\ kblankenship@tnc.org (K.B.); kimberly.hall@tnc.org (K.R.H.);jim_smith@tnc.org (J.S.); \\ meg.dettenmaier@tnc.org (M.D.); shagen@tnc.org (S.H.) \\ * Correspondence: rswaty@tnc.org
}

Citation: Swaty, R.; Blankenship, K.; Hall, K.R.; Smith, J.; Dettenmaier, M.; Hagen, S. Assessing Ecosystem Condition: Use and Customization of the Vegetation Departure Metric. Land 2022, 11, 28. https:// doi.org/10.3390/land11010028 Academic Editors: Patrick J. Comer and Reed F. Noss

Received: 8 December 2021

Accepted: 21 December 2021

Published: 24 December 2021

Publisher's Note: MDPI stays neutral with regard to jurisdictional claims in published maps and institutional affiliations.

Copyright: (C) 2021 by the authors. Licensee MDPI, Basel, Switzerland. This article is an open access article distributed under the terms and conditions of the Creative Commons Attribution (CC BY) license (https:// creativecommons.org/licenses/by/ $4.0 /)$.

\begin{abstract}
Assessment of ecosystem change often focuses on the degree of conversion and representation in networks of protected areas. While essential, these factors alone do not provide a holistic index of ecosystem conditions. Metrics that compare the current state of ecosystems to a meaningful reference condition can help identify "hidden" risks, lost functions, and provide conservation and management-relevant insights. Here we review a departure metric that can be used to measure ecosystem conditions and its implementation for all lands in the United States by the LANDFIRE Program. We then use two case studies to demonstrate how manually calculating the departure metric is used to explore under- and over-representation of structural stages. Finally, we document the assumptions, interpretation, and limitations of the departure metric, and discuss its current and possible future applications.
\end{abstract}

Keywords: ecosystem assessment; ecosystem condition; LANDFIRE; vegetation departure; vegetation structure

\section{Introduction}

Ecosystems consist of species and environmental site factors that interact through suites of processes, and often change over time through characteristic successional pathways, and in response to disturbance [1]. Understanding the variety and complexity of ecosystems is a compelling area of research and can provide vital information on how to protect at-risk species and sustain critical ecosystem services that support people and human societies [2,3]. Conservationists and policymakers are increasingly advocating for and applying ecosystem-level approaches for assessing risks to biodiversity and identifying conservation priorities $[4,5]$. This shift toward ecosystem-based assessments recognizes that using species-focused risk assessments to identify conservation priorities is costly, often biased toward vertebrates, and does not address critical processes, species interactions, or ecosystem services [6-9].

At global and regional scales, two measures, extent and representation, are frequently used to assess the conservation status of ecosystems. Quantifying extent is a common first step in evaluating ecosystem status $[10,11]$, and is part of the assessment criteria established by the International Union for Conservation of Nature's Red List of Ecosystems [1]. The second common measure, representation, evaluates how much of an ecosystem's extent is represented in the protected areas network, and can reveal "gaps" in protection, e.g., [12-15]. Representation of ecosystems in protected areas is linked to multiple protection goals such as those developed in the Convention on Biological Diversity's Aichi Biodiversity Targets [16] and the " $30 \times 30$ " Executive Order in the United States (U.S.), which aims to conserve $30 \%$ of U.S. land and water by 2030 [17]. When ecosystems are used as proxies for the associated full range of species biodiversity, the analyses of representation and extent serve as components of a "coarse filter" approach [18-20].

Assessments that rely on level of protection and geographic extent may be misleading, because they miss important indicators of ecosystem conditions that may threaten an 
ecosystem's viability. While often essential, legal protection of an area does not safeguard an ecosystem from many ecological risks [21-24]. Threats such as altered disturbance regimes, changes in land use, invasion by exotic species, changes in climate drivers, and even war can degrade ecosystem conditions, and potentially promote transformation to different ecosystem types [25-27]. For example, Swaty et al. [28] found that adding a measure of ecosystem health to a protected area assessment increased the count of critically endangered ecosystem types by $156 \%$ when compared with metrics based on representation alone.

In addition to extent and representation, the addition of an assessment of ecosystem condition, as indicated by the proportion of the extent of an ecosystem that is in each of the various successional and/or structural stages identified for that specific ecosystem type, is a key component of assessing ecosystem integrity [5,21]. Structural characteristics such as canopy height and cover change through successional processes and in response to disturbance, which in turn influence many traits of an ecosystem including microclimate [29-31], carbon sequestration [32,33], and biodiversity patterns that relate to variations in habitat suitability [34-36]. While species composition also changes through succession and in response to disturbance, here we emphasize height and cover, as these characteristics can be measured over large extents with remotely-sensed data. Changes in the number or relative abundance of structural stages (e.g., loss of an early or late structural stage) on the landscape can indicate ecosystem stressors such as disruptions in disturbance regimes (e.g., fire suppression or logging) or invasion by exotic species, and help inform conservation priorities [37-39].

Building from previous work [40,41], Hann and Strohm [42] developed a metric called Vegetation Departure (VDEP) that quantitatively measures the condition of an ecosystem by comparing the current and "reference" proportion of structural stages (VDEP methods described below). VDEP is similar to components of the "Ecosystem Integrity" defined by Nicholson et al. [5], and its calculation methods are akin to the time since disturbance approach developed by Tulloch et al. [43]. The LANDFIRE Program delivers a spatial layer depicting VDEP for the U.S. [44]. The VDEP metric was developed and is often applied to inform ecosystem management across multiple ecosystem types, and set conservation priorities, e.g., [45-49]. While valuable for regional and national applications in the U.S., the VDEP spatial layer delivered by LANDFIRE does not offer specific structural information about individual ecosystems, and is limited in where it can be applied, as the "encyclopedia of ecosystems" (i.e., set of models for all ecosystems, [50]) that inform the reference proportions have as yet only been created for the U.S. Further, VDEP uses the time period just prior to European colonization for defining "reference" values that may or may not be relevant depending on conservation goals. However, by manually calculating VDEP with other LANDFIRE products (for the U.S.), or similar resources, users can quantify the difference between reference and current structural stage measurements. Additionally, by manually calculating VDEP it is possible to customize inputs to increase local relevancy, such as setting locally meaningful "reference" values which may be more of a "desired future condition."

The objective of this paper is to describe and demonstrate an approach that allows users to add a measure of vegetation structural characteristics to ecosystem assessments. We first review the basic departure metric, and its spatial implementation by LANDFIRE for all lands in the U.S. in the VDEP spatial layer. Then, using two case studies we demonstrate how calculating VDEP manually offers additional insight into the specific structural characteristics that comprise ecosystem conditions. Finally, we discuss options and data for calculating VDEP without LANDFIRE products (e.g., for locations outside of the U.S., or for applications requiring further customization of ecosystem classes). Our intent is to present the use of a simple metric that once calculated, will inform a comprehensive evaluation of at-risk ecosystems while focusing conservation not only on representation or expansion of ecosystem extent, but also on improving ecosystem conditions. 


\section{Methods: Departure and Vegetation Departure}

\subsection{Outline for Methods}

In this section we: (1) review the concept and math behind departure, (2) describe how LANDFIRE measures departure in its VDEP spatial layer, and (3) present considerations for the inputs required to calculate VDEP (Box 1, includes comments on ways to implement outside of the U.S.).

\subsection{Introduction to Departure}

Departure is a metric that can be used as an indicator of ecosystem condition-it suggests the degree to which an observed set of classes "is departed from" what one would expect based on a reference condition. Departure is the inverse of similarity, which is a common concept in ecology and the ecological literature [51,52]. A similarity metric compares two data sets comprised of different units (e.g., species, ecosystems), in different proportions (e.g., number of individual, number of pixels in extent) to determine how and how much they are alike. Because departure is the inverse of similarity, departure describes how and by how much the two data sets are different (Table 1).

Table 1. Departure quantifies the difference between two data sets and is the inverse of similarity.

\begin{tabular}{cccccc}
\hline Class & $\begin{array}{c}\text { Data Set A } \\
\text { Value }\end{array}$ & $\begin{array}{c}\text { Data Set B } \\
\text { Value }\end{array}$ & $\begin{array}{c}\text { Similarity } \\
\text { (Minimum of } \\
\text { Data set A and B) }\end{array}$ & $\begin{array}{c}\text { Sum of } \\
\text { Similarity }\end{array}$ & $\begin{array}{c}\text { Departure (100 } \\
\text { - Similarity) }\end{array}$ \\
\cline { 1 - 4 } Class 1 & 10 & 15 & 10 & \multirow{2}{*}{75} & 25 \\
\cline { 1 - 4 } Class 2 & 30 & 15 & 15 & \\
\cline { 1 - 3 } Class 3 & 50 & 40 & 10 & \\
\hline
\end{tabular}

The departure metric is defined as:

$$
\text { Departure }=100-\text { Similarity }
$$

where Similarity $=\sum\left(\min \left(\mathrm{A}_{\mathrm{i}}, \mathrm{B}_{\mathrm{i}}\right)\right)$ over all classes $\mathrm{i}, \ldots \mathrm{n}$

Alternatively, an equivalent formulation of the Departure metric is:

$$
\begin{gathered}
\text { Departure }=\operatorname{Sum}\left(\operatorname{Abs}\left[A_{i}-B_{i}\right]\right) / 2 \text {, or the sum of linear distances } \\
\text { Departure }=\operatorname{Sum}\left(\operatorname{Abs}\left[A_{i}-B_{i}\right]\right) / 2=100-\text { Similarity }
\end{gathered}
$$

This formulation of a departure metric assumes the sum of all class values in a data set is 100 , e.g., percent of a landscape in each class. The specific interpretation of the departure results depends on the nature of the two data sets being compared.

All metrics are built upon key assumptions. The key assumptions of the departure metric described in this paper are:

1. The data sets being compared are representative of the populations of interest; i.e., are the different classes in the two data sets accurate enough to provide meaningful results when compared?

2. The data sets being compared are compatible thematically; i.e., Class should represent the same condition in the two data sets being compared.

3. The sample frame used to develop the data sets is sufficient to represent the populations of interest; i.e., is the area of application large enough to likely contain a representative set of all the classes. 


\subsection{LANDFIRE Vegetation Departure}

LANDFIRE measures and maps VDEP for all lands in the U.S. [44] (Figure 1). VDEP is an important component of the LANDFIRE product suite because it can identify conditions that relate to fire and resource management needs and guide management activities. LANDFIRE VDEP is based on an earlier implementation of a vegetation departure metric called Fire Regime Condition Class [53], which is itself derived from the ecological departure metric described above. LANDFIRE uses a specific implementation of the general departure metric to meet program goals related to very large landscape, regional, and national scale analyses for wildland fire and natural resource management [44]. Applying departure concepts to smaller geographies may require adjusting LANDFIRE computation methods, modifying LANDFIRE products to more accurately represent local conditions, or using other data sets (see Box 1 for VDEP input data considerations).

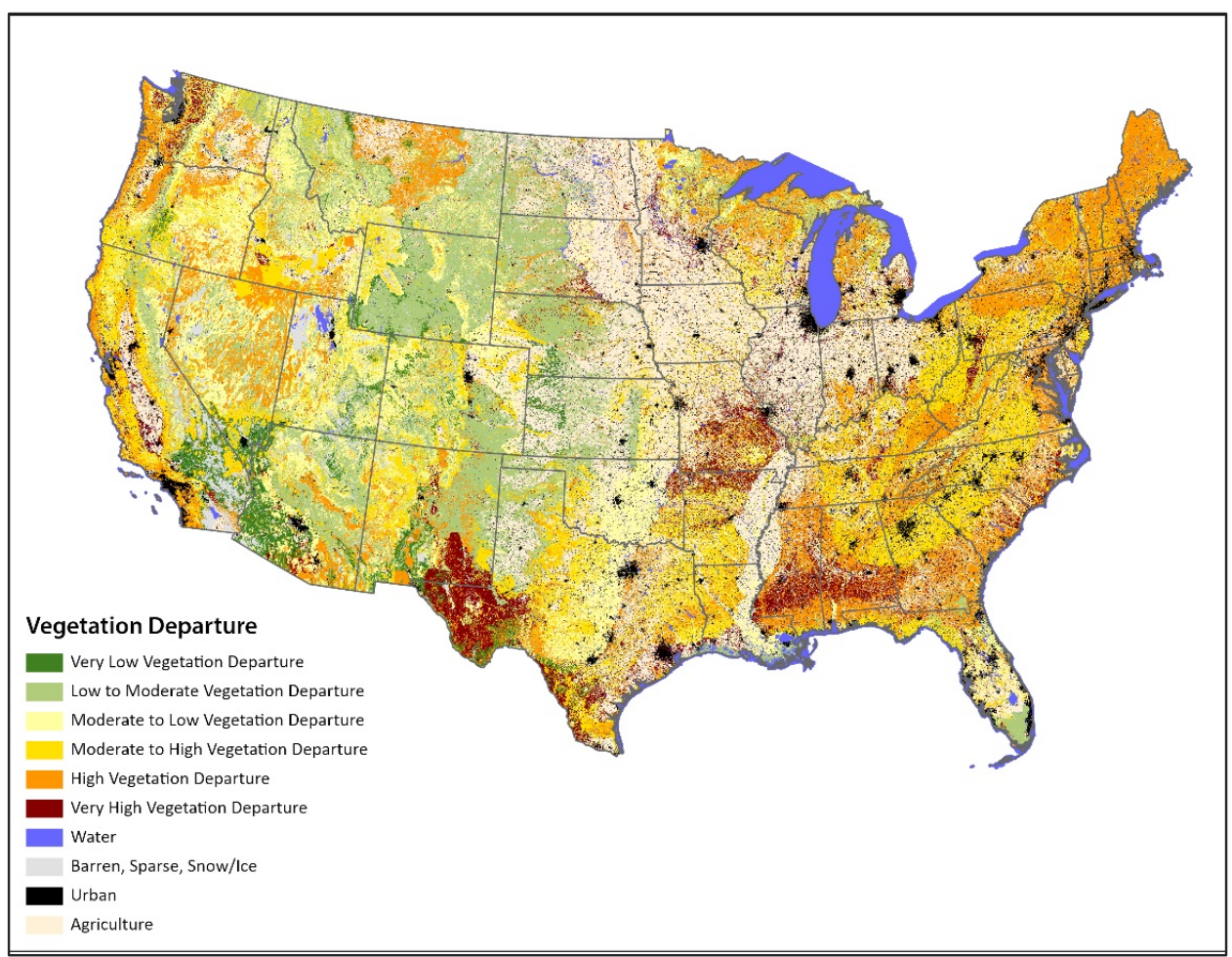

Figure 1. The LANDFIRE Vegetation Departure spatial layer [54] depicts the difference between a pre-European colonization reference condition and current conditions.

In the LANDFIRE VDEP spatial layer [54], a single departure value is assigned to each ecosystem over the area of interest using the simple departure metric described above. LANDFIRE VDEP utilizes "Reference" and "Current" as the two data sets being compared and defines "Class" as the structural stages (called succession classes) of an ecosystem. Reference data in LANDFIRE are called Biophysical Settings (BpS) and are intended to represent pre-European colonization ecosystem dynamics and conditions.

The actual reference values used in LANDFIRE VDEP are the outputs of more than 900 individual, quantitative state-and-transition simulation models, called BpS models [50,55]. LANDFIRE also produces a BpS spatial layer [56] representing pre-colonization vegetation patterns which serves as the geographic extent for the VDEP calculation, identifying where ecosystems occurred in the reference period. Current vegetation amount is measured from the succession classes spatial layer [57], which depicts the location of structural stages for each BpS. A succession class in LANDFIRE is created from combinations of existing vegetation type, existing vegetation height, and existing vegetation cover using rules specified by experts in the BpS models [50]. LANDFIRE also maps two "uncharacter- 
istic" classes to identify current conditions that are absent from the reference conditions. The uncharacteristic native (UN) class represents areas of native vegetation conditions that would not have occurred in the reference condition (e.g., native trees encroaching into sagebrush). The uncharacteristic exotic (UE) class captures all non-native vegetation (e.g., cheatgrass, Bromus tectorum). Note that LANDFIRE excluded non-vegetated and sparsely vegetated areas from the VDEP computation since they do not have defined succession classes. LANDFIRE also excluded areas mapped as agriculture and urban from the computation since by definition their departure value would be 100 .

Departure also requires us to specify the landscape for which the values are computed, called the summary unit. In LANDFIRE, the VDEP summary unit is defined as the area with unique reference conditions for each individual BpS. Reference conditions for a $\mathrm{BpS}$ are outputs of the BpS models for an individual National Land Cover Database (NLCD) map zone or group of map zones [58]. Each BpS will have one VDEP value in each summary unit. This summary unit is important to consider when interpreting VDEP as delivered by LANDFIRE, or any other implementation of a departure metric. It is a landscape scale metric, and the extent of the landscape assessed is necessary for interpreting the metric.

Box 1. Vegetation Departure Inputs: sources and considerations.

There are several considerations for individuals interested in the spatial calculation of VDEP using LANDFIRE or other data sets. When using data created by others, including LANDFIRE, we recommend that users review and modify all inputs as needed to meet their objectives. Note that the input data for calculating VDEP need to be thematically consistent, for example, a class defined in the reference condition must be defined in the same way for mapping current conditions. All spatial data must have the same extent, pixel cell size, and projection. Below are additional considerations specific to individual VDEP inputs.

Reference conditions. Reference conditions may be any baseline of interest and can represent any time period from the past to the future. Historical or future range of variability or even desired future condition can be used as a baseline from which departure is measured. Methods for developing reference conditions include simulation modeling e.g., [50], expert opinion, historical maps, survey data, and reference sites (i.e., sites similar to the reference condition).

Reference ecosystem extent. When using existing data sets users should consider aggregating or splitting the ecosystem types to achieve the level of thematic detail needed to meet their objectives. For example, a user interested in broadly defined forest types might aggregate the eight oakdominated BpS mapped by LANDFIRE in Wisconsin into one oak forest type. In the U.S., potential vegetation type maps are often used to define reference ecosystem extent [38]. Data sets such as those described by Hengl et al. [59] or Sayre et al. [15] may be used to get at this input in other countries, as long as the reference conditions are defined for the same ecosystems.

Current conditions. VDEP can include any number or type (e.g., agriculture) of classes, e.g., [60], but defining mappable classes can be challenging. For example, LANDFIRE defined its current condition structural stages (succession classes) solely based on the overstory vegetation because it is difficult to map under- and mid-story vegetation from remotely sensed images. A variety of attributes can be used to define current condition structural stages including species composition, canopy cover, vegetation height, tree diameter, or stand age. Often regional or local spatial layers are available that can be used to create a current condition map, e.g., [38]. Stand exams, inventory and monitoring data, and vegetation plot data can all be used to map current conditions. There are global vegetation height, e.g., [61] and tree canopy cover e.g., [62] data that can serve as building blocks for this input. Local or regional data sets, if available may be more appropriate.

Summary Unit. The key question that must be answered to define the summary unit is: how large of an area is needed to potentially encompass the full suite of structural stages in their reference proportions? This is sometimes referred to as minimum dynamic area and should account for disturbances and other ecological processes [63]. Summary unit size will likely change based on the focal ecosystem(s). Coastal forests in Oregon that historically experienced large but infrequent fires may need a larger summary unit [64] when compared with inland vegetation types in Utah where fire events are more frequent [65]. Selection of a summary unit that is too small may not capture ecological variation, while a unit that is too large can mask effects of management [66]. Experimenting with units of various sizes may help determine an appropriate summary unit, e.g., [65]. The summary unit is ideally an ecologically meaningful boundary, such as ecoregions or watersheds, but administrative or political units, such as park boundaries or states, can also be useful. 


\section{Case Studies and Results}

\subsection{Methods for Case Studies}

Here we use two case studies to illustrate how the VDEP metric can contribute to an ecosystem assessment and provide management-relevant insight into vegetation conditions for two extensive and well-protected ecosystems: the Laurentian-Acadian Northern Hardwoods Forest (Northern Hardwoods hereafter; [67]), and the Inter-Mountain Basins Big Sagebrush Steppe (Sagebrush Steppe hereafter; [68]). For this analysis we spatially combined the LANDFIRE BpS [56], succession class [57], existing vegetation type [69], existing vegetation cover [70], and existing vegetation height [71] spatial layers with a spatial layer representing U.S. protected areas [72] in GIS software (ESRI ArcGIS Pro Version 2.8.1 and ArcMap version 10.8). From that spatial combine we first summed the amount of each ecosystem in the BpS spatial layer to calculate the historical extent. Next, we calculated conversion as the sum of agricultural and urban classes identified in the succession class spatial layer and the area permanently protected from conversion as the sum of areas identified with a GAP status code of one, two, or three within the protected areas spatial layer. Then, we calculated VDEP by (1) summarizing the current amount of structural stages in the succession class spatial layer and (2) comparing that to the reference conditions from the BpS model for each ecosystem (Figure 2). Finally, we identified the characteristics of the existing vegetation type, cover, and height classified as UN and UE in the succession class spatial layer.

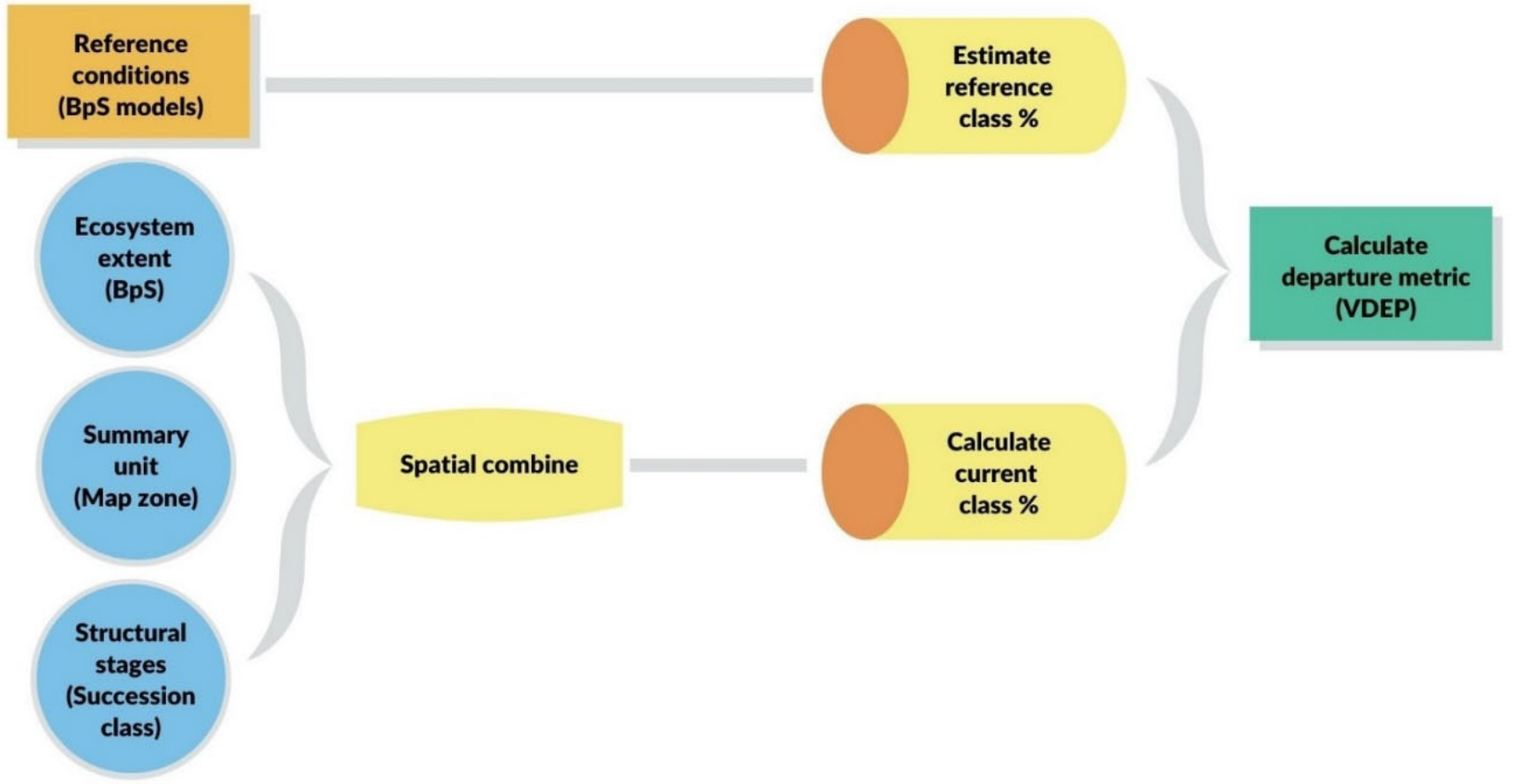

Figure 2. Workflow for calculating VDEP. On the left are the VDEP inputs with LANDFIRE equivalent products in parentheses. The spatial combine is done in a GIS and results in the percentage of current structural stages. The reference amount of each structural stage is estimated from the BpS model results. The current and reference class percentages are compared to calculate departure. 


\subsubsection{Case Study 1. Northern Hardwoods Results}

The Northern Hardwoods forest is an iconic ecosystem in the northeastern region of the U.S. characterized by tree species such as sugar maple (Acer saccharum), eastern hemlock (Tsuga canadensis), yellow birch (Betula alleghaniensis), eastern white pine (Pinus strobus), and balsam fir (Abies balsamea). These forests occur on ground and end moraines with a dominant soil texture of sandy loam ([67]). Historically, the dominant disturbance was thought to be windthrow, both larger, high-severity events ( 1000-year return interval) and more frequent, smaller events ( 50-240-year return interval) [73,74]. This disturbance regime, dominated by small-scale events, yielded a forest dominated by later-successional (structural) stages. During the late 1800s and early 1900s, extensive cutting removed almost all of the mature white pine and eastern hemlock, an event referred to locally as "the great cutover"[75]. The current dominant disturbance is often single-tree selection harvest that commonly entails removal of "less-desirable" timber species (e.g., balsam fir or spruce) and trees with forest health issues. This type of harvest creates openings that are smaller than the typical natural disturbance (e.g., from wind, fire, or insects). The current dominant harvest practices in addition to the great cutover, have resulted in a homogenization of this forest with a substantial increase in sugar maple and the decline of moderately-shade tolerant species such as yellow birch [76,77]. The Northern Hardwoods BpS covers approximately 7.9 million hectares currently (Figure 3A). Today $22 \%(1,746,245 \mathrm{ha})$ of the BpS is permanently protected, with most being in GAP status 3 $(\sim 10 \%)$, which prevents fragmentation but allows extractive activities. Approximately $23 \%$ of the original ecosystem extent has been converted to agricultural land use, and about $7 \%$ to urban land uses.

Driven by a substantial underrepresentation of the late succession, shade-tolerant structural stage and an overrepresentation of the late succession- shade-intolerant structural stage (Figure 3), the vegetation Departure value for the Northern Hardwoods in the Great Lakes region is $82 \%$. Currently there is a relative overrepresentation of the moderately shade-tolerant Aspen, Birch, Sugar Maple and Basswood structural stage (referred to as "late-intolerant" in figure). Adding to the complexity, we found a substantial amount $(19 \%)$ of UN and $9 \%$ UE on the landscape. Approximately $93 \%$ of the pixels labeled as UN had uncharacteristically low canopy cover (i.e., canopy cover $<60 \%$ for trees $>10 \mathrm{~m}$ tall), which is consistent with forest harvesting practices. The UE lands were primarily forest plantations $(89,636 \mathrm{ha})$ and ruderal vegetation types $(432,733 \mathrm{ha})$. This holistic analysis allows managers to paint a more complete picture of this ecosystem. In short, the Northern Hardwoods of the Great Lakes region (1) are fairly well represented in the protected areas network, (2) have a relatively low rate of conversion to agricultural and urban land uses, (3) have high levels of vegetation departure driven by underrepresentation of the late structural stage and the presence uncharacteristic structural stages.

\subsubsection{Case Study 2. Sagebrush Steppe Results}

Sagebrush communities occupy vast swaths of the American west and are home to species of conservation concern such as the greater sage-grouse (Centrocercus urophasianus) [78]. Sagebrush Steppe historically occupied more than 5.2 million hectares (Figure 3B) and is characterized by perennial grasses, forbs, and big sagebrush (Artemisia tridentata) [68]. Sagebrush Steppe has a relatively low rate of conversion (18\% converted to agriculture and $3 \%$ converted to urban land uses) and a relatively high rate of protection. Today $58 \%(3,039,415 \mathrm{ha})$ of the $\mathrm{BpS}$ is permanently protected, but sagebrush communities face many threats. Across the west these communities are losing their native herbaceous understory [79-81] and have been widely invaded by non-native annual grasses, especially cheatgrass (Bromus tectorum). Cheatgrass is implicated in changing the fire frequency and vegetation dynamics of the ecosystem [82,83]. Native trees such as juniper (Juniperus spp.) and pinyon pine (Pinus monophylla and P. edulis) are also expanding into sagebrush further altering the ecosystem [84]. 

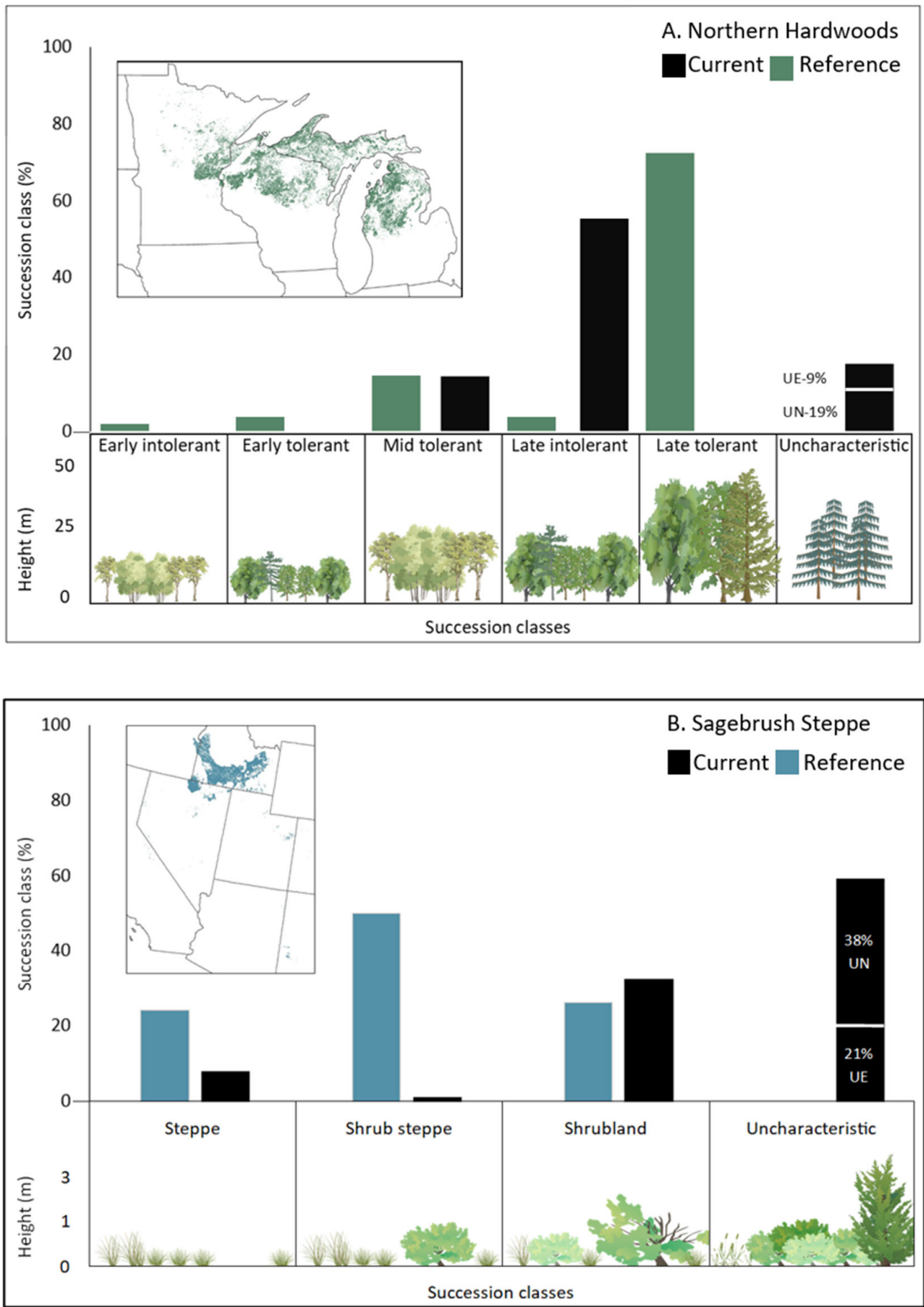

Figure 3. A comparison of reference and current structural stage (i.e., succession class) amounts for (A)) Northern Hardwoods and (B)) Sagebrush Steppe show high vegetation departure. Each panel has a map representing the ecological extent, depictions of the individual structural stages (names shortened), and a bar chart comparing reference to current amounts of each structural stage. Vegetation graphics credit: Integration and Application Network (ian.umces.edu/media-library).

Despite its low level of conversion and high rate of protection, the Sagebrush Steppe ecosystem is highly departed from reference conditions (Figure 3B), with a VDEP value of $65 \%$. The results of our analysis show that the Steppe and Shrub steppe structural stages are under-represented and that the Shrubland structural stage is over-represented today compared to the reference condition. In addition, more than half of the BpS is in an uncharacteristic structural stage today. We calculated 53,473 ha of tree encroachment 
(identified as UN) and 337,006 ha of non-native annual grasslands (identified as UE) within the Sagebrush Steppe. It is important to note that LANDFIRE likely under-estimates the presence of invasive annual grasses because it does not measure grasses within the understory of pixels classified as shrubs or trees. Although it is not possible to directly measure understory composition using the remotely sensed imagery that LANDFIRE spatial layers are based on, the reduction in herbaceous dominated stages (e.g., Steppe and Shrub steppe) and the increase in woody dominated stages (Sagebrush and UN) is consistent with the loss of the herbaceous component within the Sagebrush Steppe ecosystem. While loss of understory, tree encroachment, and invasion by non-native species have been described for sagebrush range-wide, this analysis quantifies the type and extent of the threats within the Sagebrush Steppe and provides mangers with specific information on ecosystem conditions that can help guide management decisions.

\section{Discussion}

VDEP offers both an overall score for ecosystem condition and quantifies over- and under- representation of specific structural stages. From a conservation perspective VDEP can bolster extent and protection metrics that focus on a single threat: conversion. Depending on its implementation, VDEP can identify and measure threats such as shifts in community composition and structure, invasive species, and the effects of altered disturbance regimes. For land managers VDEP offers specific information from which ecosystem management goals and actions can be developed and supports prioritization efforts [38,60]. Additionally, these methods adhere to relevant indicators in certification and assessment protocols such as the Forest Stewardship Council-US standards [85], the U.S. Forest Service planning rule [86], and those proposed by Nicholson et al. within the "Ecological Integrity" component of ecological goal setting [5].

\subsection{Challenges and Their Implications}

As with any single model or ecosystem metric, there are limitations and challenges to the application of vegetation departure. We highlight two general considerations for users of the departure metric and three considerations related to the use of LANDFIRE VDEP. First, an overarching challenge for individuals wanting to calculate departure spatially is finding or creating the required inputs. Using existing data sets can save time, but users should plan to review and modify those data as needed to meet their needs. Creating the inputs requires time and resources, but does allow the user more control over the characteristics of the data (e.g., scale, attributes). A second general consideration is that vegetation departure does not capture spatial patterns such as patch sizes, or other aspects of landscape heterogeneity. Additional information is needed to assess these ecologically important elements. A specific limitation of LANDFIRE VDEP is that it defines and measures structural stages primarily as function of canopy cover and height. While these are important ecosystem attributes, they may not fully capture biodiversity, carbon sequestration, or other values such as wildfire risk. Additionally, it may be difficult to determine species composition for under- and mid-story vegetation using LANDFIRE spatial layers or other remotely sensed products. We suggest additional analyses to ensure that important understory species shifts are not overlooked. Lastly while comparing current conditions to historical reference conditions (as LANDFIRE does) may not be illustrative for management in a changing climate (see [87]), other baselines for vegetation classes can be used. For example, users may want to measure departure from a modeled or desired future condition to integrate changes in disturbance regimes, novel ecosystem dynamics, and species shifts.

\subsection{Innovative Work and Future Opportunities}

Examples from the literature demonstrate applications and innovations of the departure concept including LANDFIRE's VDEP spatial layer [54]. Walston and Hartmann [88] demonstrate use of LANDFIRE's VDEP spatial layer as a base data set in the develop- 
ment of their Landscape Integrity Index, serving as an indicator of ecological integrity. Vogler et al. [46] used VDEP to create treatment objectives for the prioritization of forest restoration in eastern Oregon. In perhaps the first customization of the VDEP concept, Low et al. [45] compared VDEP values between different management scenarios and incorporated a return-on-investment component. Building on VDEP concepts, Haugo et al. [38] combined LANDFIRE and local spatial products to evaluate forest structure restoration needs in Oregon and Washington. Building on the original VDEP concepts, Provencher et al. [60] created an expanded VDEP formula called "Unified Ecological Departure" that adjusts the VDEP index based on "undesirable" structural stages (defined by stakeholders), adds a threshold value for specific structural stages, and uses a high-risk function to weight specific structural stages.

We hope to see the continued refinement of the LANDFIRE VDEP product and inputs. Ideally, we would like to see a massive geographic expansion from the U.S. to a global reference model set, which we recognize as a huge task e.g., [50], but an important, collaborative endeavor. A global set of models would allow for the quantification of reference conditions (defined as any baseline of interest) that could be compared to recent global ecosystem maps such as those by Sayre et al. [15] to measure departure. Inspired by Provencher et al. [60], we propose departure tracking of additional attributes with the objective of linking them to broad structural stages representing wildlife habitat, ecosystem services, and human-centric values. These linkages would allow for the calculation of additional and nuanced departure values.

\section{Conclusions}

Clear and actionable assessments of ecosystem conditions are needed to protect at risk species and sustain ecosystem services. The departure metric provides a tool for measuring ecosystem conditions and can identify and quantify "hidden" ecosystem risks, guide management actions, and provide conservation related insights. While LANDFIRE products provide a starting point for departure assessments in the U.S., other data sets can be used in their absence or to better reflect local conditions or goals. By strengthening our understanding of ecosystem conditions, vegetation departure analyses can supplement assessments of ecosystem extent and representation.

Author Contributions: Conceptualization, R.S., K.B., K.R.H., J.S., M.D. and S.H.; Data curation, R.S. and S.H.; Formal analysis, R.S., K.B. and S.H.; Investigation, K.R.H.; Methodology, R.S. and K.B.; Supervision, J.S.; Visualization, R.S., K.B., M.D. and S.H.; Writing-original draft, R.S., K.B., K.R.H., J.S. and M.D.; Writing-review \& editing, R.S., K.B., K.R.H., J.S. and M.D. All authors have read and agreed to the published version of the manuscript.

Funding: This analysis was supported through TNC LANDFIRE Cooperative Agreement CA-1811132543-049 with the U.S. Forest Service Fire and Aviation and Department of the Interior Office of Wildland Fire.

Acknowledgments: We would like to thank Stacy Cotey, Garrett Johnson, and Stacey Marion of the Conservation Data Lab for constructive comments. We are grateful for important comments and advice from Joe Bailey and three anonymous reviewers. We also thank ESRI for making ArcGIS software freely available to The Nature Conservancy.

Conflicts of Interest: The authors declare no conflict of interest. The funders had no role in the design of the study; in the collection, analyses, or interpretation of data; in the writing of the manuscript, or in the decision to publish the results.

\section{References}

1. IUCN. Guidelines for the Application of IUCN Red List of Ecosystems Categories and Criteria, Version 1.0; Bland, L.M., Keith, D.A., Murray, N.J., Rodriguez, J.P., Eds.; International Union for Conservation of Nature: Gland, Switzerland, 2015.

2. Noss, R.F. Indicators for monitoring biodiversity-A hierarchical approach. Conserv. Biol. 1990, 4, 355-364. [CrossRef]

3. Kremen, C. Managing ecosystem services: What do we need to know about their ecology? Ecol. Lett. 2005, 8, 468-479. [CrossRef] 
4. Watson, J.E.M.; Keith, D.A.; Strassburg, B.B.N.; Venter, O.; Williams, B.; Nicholson, E. Set a global target for ecosystems. Nature 2020, 578, 360-362. [CrossRef] [PubMed]

5. Nicholson, E.; Watermeyer, K.E.; Rowland, J.A.; Sato, C.F.; Stevenson, S.L.; Andrade, A.; Brooks, T.M.; Burgess, N.D.; Cheng, S.-T.; Grantham, H.S.; et al. Scientific foundations for an ecosystem goal, milestones and indicators for the post-2020 global biodiversity framework. Nat. Ecol. Evol. 2021, 5, 1338-1349. [CrossRef] [PubMed]

6. Franklin, J.F. Preserving biodiversity: Species, ecosystems, or landscapes? Ecol. Appl. 1993, 3, 202-205. [CrossRef] [PubMed]

7. Noss, R.F. Ecosystems as conservation targets. Trends Ecol. Evol. 1996, 11, 351. [CrossRef]

8. Cowling, R.M.; Knight, A.T.; Faith, D.P.; Ferrier, S.; Lombard, A.T.; Driver, A.; Rouget, M.; Maze, K.; Desmet, P.G. Nature conservation requires more than a passion for species. Conserv. Biol. 2004, 18, 1674-1676. [CrossRef]

9. Keith, D.A.; Rodríguez, J.P.; Rodríguez-Clark, K.M.; Nicholson, E.; Aapala, K.; Alonso, A.; Asmussen, M.; Bachman, S.; Basset, A.; Barrow, E.G.; et al. Scientific foundations for an IUCN Red List of Ecosystems. PLoS ONE 2013, 8, e62111. [CrossRef]

10. Maes, J.; Driver, A.; Czúcz, B.; Keith, H.; Jackson, B.; Nicholson, E.; Dasoo, M. A review of ecosystem condition accounts: Lessons learned and options for further development. One Ecosyst. 2020, 5. [CrossRef]

11. Farrell, C.; Coleman, L.; Kelly-Quinn, M.; Obst, C.; Eigenraam, M.; Norton, D.; O’Donoghue, C.; Kinsella, S.; Delargy, O.; Stout, J. Applying the System of Environmental Economic Accounting-Ecosystem Accounting (SEEA-EA) framework at catchment scale to develop ecosystem extent and condition accounts. One Ecosyst. 2021, 6, e65582. [CrossRef]

12. Scott, J.M.; Davis, F.; Csuti, B.; Noss, R.; Butterfield, B.; Groves, C.; Anderson, H.; Caicco, S.; D’Erchia, F.; Edwards, T.C., Jr.; et al. Gap analysis: A geographic approach to protection of biological diversity. Wildl. Monogr. 1993, 123, 3-41.

13. Hoekstra, J.M.; Boucher, T.M.; Ricketts, T.H.; Roberts, C. Confronting a biome crisis: Global disparities of habitat loss and protection. Ecol. Lett. 2005, 8, 23-29. [CrossRef]

14. Aycrigg, J.L.; Davidson, A.; Svancara, L.K.; Gergely, K.J.; McKerrow, A.; Scott, J.M. Representation of ecological systems within the protected areas network of the continental United States. PLoS ONE 2013, 8, e54689. [CrossRef]

15. Sayre, R.; Karagulle, D.; Frye, C.; Boucher, T.; Wolff, N.H.; Breyer, S.; Wright, D.; Martin, M.; Butler, K.; Van Graafeiland, K.; et al An assessment of the representation of ecosystems in global protected areas using new maps of World Climate Regions and World Ecosystems. Glob. Ecol. Conserv. 2020, 21, e00860. [CrossRef]

16. CBD. Strategic Plan. for Biodiversity 2011-2020, Including Aichi Biodiversity Targets; Secretariate of the Convention on Biological Diversity, UN Environment Programme: Nairobi, Kenya, 2011. Available online: https://www.cbd.int/sp/ (accessed on 17 September 2021).

17. E.O. 14008 of 27 January 2021. Tackling the Climate Crisis at Home and Abroad. 86 FR 7619. Executive Office of the President, 2021-02177. Available online: https: / / www.federalregister.gov/documents/2021/02/01/2021-02177/tackling-the-climate-crisisat-home-and-abroad (accessed on 26 October 2021).

18. Noss, R.F. From plant communities to landscapes in conservation inventories: A look at The Nature Conservancy (USA). Biol. Conserv. 1987, 41, 11-37. [CrossRef]

19. Hunter, M.L., Jr.; Jacobson, G.L., Jr.; Webb, T., III. Paleoecology and the coarse-filter approach to maintaining biological diversity. Conserv. Biol. 1988, 2, 375-385. [CrossRef]

20. Groves, C.R. Drafting a Conservation Blueprint; Island Press: Washington, DC, USA, 2003.

21. Parrish, J.D.; Braun, D.P.; Unnasch, R.S. Are we conserving what we say we are? Measuring ecological integrity within protected areas. Bioscience 2003, 53, 851-860. [CrossRef]

22. Gaston, K.J.; Jackson, S.F.; Cantú-Salazar, L.; Cruz-Piñón, G. The ecological performance of protected areas. Annu. Rev. Ecol. Evol. Syst. 2008, 39, 93-113. [CrossRef]

23. Pringle, R.M. Upgrading protected areas to conserve wild biodiversity. Nature 2017, 546, 91-99. [CrossRef]

24. Schulze, K.; Knights, K.; Coad, L.; Geldmann, J.; Leverington, F.; Eassom, A.; Marr, M.; Butchart, S.H.M.; Hockings, M.; Burgess, N.D. An assessment of threats to terrestrial protected areas. Conserv. Lett. 2017, 11, e12435. [CrossRef]

25. McDonald, R.I.; Kareiva, P.; Forman, R.T.T. The implications of current and future urbanization for global protected areas and biodiversity conservation. Biol. Conserv. 2008, 141, 1695-1703. [CrossRef]

26. Daskin, J.H.; Pringle, R.M. Warfare and wildlife declines in Africa's protected areas. Nature 2018, 553, 328-332. [CrossRef] [PubMed]

27. Tabor, K.; Hewson, J.; Tien, H.; González-Roglich, M.; Hole, D.; Williams, J.W. Tropical protected areas under increasing threats from climate change and deforestation. Land 2018, 7, 90. [CrossRef]

28. Swaty, R.; Blankenship, K.; Hagen, S.; Fargione, J.; Smith, J.; Patton, J. Accounting for ecosystem alteration doubles estimates of conservation risk in the conterminous United States. PLoS ONE 2011, 6, e23002. [CrossRef]

29. Franklin, J.F.; Van Pelt, R.S. Spatial aspects of structural complexity in old-growth forests. J. For. 2004, 102, 22-28. [CrossRef]

30. Jucker, T.; Hardwick, S.R.; Both, S.; Elias, D.M.O.; Ewers, R.M.; Milodowski, D.T.; Swinfield, T.; Coomes, D.A. Canopy structure and topography jointly constrain the microclimate of human-modified tropical landscapes. Glob. Chang. Biol 2018, 24, 5243-5258. [CrossRef] [PubMed]

31. Zellweger, F.; De Frenne, P.; Lenoir, J.; Vangansbeke, P.; Verheyen, K.; Bernhardt-Römermann, M.; Baeten, L.; Hédl, R.; Berki, I.; Brunet, J.; et al. Forest microclimate dynamics drive plant responses to warming. Science 2020, 368, 772-775. [CrossRef]

32. Ma, L.; Hurtt, G.; Tang, H.; Lamb, R.; Campbell, E.; Dubayah, R.; Guy, M.; Huang, W.; Lister, A.; Lu, J.; et al. High-resolution forest carbon modelling for climate mitigation planning over the RGGI region, USA. Environ. Res. Lett. 2021, 16, 045014. [CrossRef] 
33. Issa, S.; Dahy, B.; Ksiksi, T.; Saleous, N. A review of terrestrial carbon assessment methods using geo-spatial technologies with emphasis on arid lands. Remote Sens. 2020, 12, 2008. [CrossRef]

34. MacArthur, R.H.; MacArthur, J.W. On bird species diversity. Ecology 1961, 42, 594-598. [CrossRef]

35. Goetz, S.J.; Steinberg, D.; Betts, M.G.; Holmes, R.T.; Doran, P.J.; Dubayah, R.; Hofton, M. Lidar remote sensing variables predict breeding habitat of a Neotropical migrant bird. Ecology 2010, 91, 1569-1576. [CrossRef]

36. Whitehurst, A.S.; Swatantran, A.; Blair, J.B.; Hofton, M.A.; Dubayah, R. Characterization of canopy layering in forested ecosystems using full waveform lidar. Remote Sens. 2013, 5, 2014-2036. [CrossRef]

37. Schwartz, N.B.; Urban, D.L.; White, P.S.; Moody, A.; Klein, R.N. Vegetation dynamics vary across topographic and fire severity gradients following prescribed burning in Great Smoky Mountains National Park. For. Ecol. Manag. 2016, 365, 1-11. [CrossRef]

38. Haugo, R.; Zanger, C.; Demeo, T.; Ringo, C.; Shlisky, A.; Blankenship, K.; Simpson, M.; Mellen-McLean, K.; Kertis, J.; Stern, M. A new approach to evaluate forest structure restoration needs across Oregon and Washington, USA. For. Ecol. Manag. 2015, 335, 37-50. [CrossRef]

39. Alexander, H.D.; Siegert, C.; Brewer, J.S.; Kreye, J.; Lashley, M.A.; McDaniel, J.K.; Paulson, A.K.; Renninger, H.J.; Varner, J.M. Mesophication of oak landscapes: Evidence, knowledge gaps, and future research. Bioscience 2021, 71, 531-542. [CrossRef]

40. Clements, F.E. The relict method in dynamic ecology. J. Ecol. 1934, 22, 39-68. [CrossRef]

41. Mueller-Dombois, D.; Ellenberg, H. Aims and Methods of Vegetation Ecology; John Wiley \& Sons: Wiley, NY, USA, 1974.

42. Hann, W.J.; Strohm, D.J. Fire regime condition class and associated data for fire and fuels planning: Methods and applications. In Fire, Fuel Treatments, and Ecological Restoration: Conference Proceedings, Fort Collins, CO, USA, 16-18 April 2002; RMRS-P-29; Omi, P.N., Joyce, L.A., Eds.; USDA Forest Service, Rocky Mountain Research Station: Fort Collins, CO, USA, 2003 ; pp. $397-433$. Available online: http:/ / www.fs.fed.us/rm/pubs/rmrs_p029.pdf (accessed on 26 October 2021).

43. Tulloch, A.I.T.; McDonald, J.; Cosier, P.; Sbrocchi, C.; Stein, J.; Lindenmayer, D.; Possingham, H.P. Using ideal distributions of the time since habitat was disturbed to build metrics for evaluating landscape condition. Ecol. Appl. 2018, 28, 709-720. [CrossRef]

44. Rollins, M.G. LANDFIRE: A nationally consistent vegetation, wildland fire, and fuel assessment. Int. J. Wildland Fire 2009, 18, 235-249. [CrossRef]

45. Low, G.; Provencher, L.; Abele, S.L. Enhanced conservation action planning: Assessing landscape condition and predicting benefits of conservation strategies. J. Conservat. Plan. 2010, 6, 36-60. Available online: http://appliedconservation.com/wpcontent/uploads/2013/07/JCP_v6_3_Low.pdf (accessed on 22 October 2021).

46. Vogler, K.C.; Ager, A.A.; Day, M.A.; Jennings, M.; Bailey, J.D. Prioritization of forest restoration projects: Tradeoffs between wildfire protection, ecological restoration and economic objectives. Forests 2015, 6, 4403-4420. [CrossRef]

47. Ager, A.A.; Day, M.A.; Vogler, K. Production possibility frontiers and socioecological tradeoffs for restoration of fire adapted forests. J. Environ. Manag. 2016, 176, 157-168. [CrossRef] [PubMed]

48. Belote, R.T.; Cooper, R.M.; Daniels, R.A. Contemporary composition of land use, ecosystems, and conservation status along the Lewis and Clark National Historic Trail. Nat. Areas J. 2017, 37, 17-29. [CrossRef]

49. Evers, C.R.; Ager, A.A.; Nielsen-Pincus, M.; Palaiologou, P.; Bunzel, K. Archetypes of community wildfire exposure from national forests of the western US. Landsc. Urban. Plan. 2019, 182, 55-66. [CrossRef]

50. Blankenship, K.; Swaty, R.; Hall, K.R.; Hagen, S.; Pohl, K.; Shlisky Hunt, A.; Patton, J.; Frid, L.; Smith, J. Vegetation dynamics models: A comprehensive set for natural resource assessment and planning in the United States. Ecosphere 2021, 12, e03484. [CrossRef]

51. Bray, R.T.; Curtis, J.T. An ordination of the upland forest communities of southern Wisconsin. Ecol. Monogr. 1957, 27, 325-349. [CrossRef]

52. Keane, R.E.; Holsinger, L.; Parsons, R.A. Evaluating Indices that Measure Departure of Current Landscape Composition from Historical Conditions (No. 83); US Department of Agriculture, Forest Service, Rocky Mountain Research Station: Fort Collins, CO, USA, 2011. [CrossRef]

53. Barrett, S.; Havlina, D.; Jones, J.; Hann, W.; Frame, C.; Hamilton, D.; Schon, K.; Demeo, T.; Hutter, L.; Menakis, J. Interagency Fire Regime Condition Class. Guidebook. Version 3.0, September 2010; USDA Forest Service, US Department of the Interior, and The Nature Conservancy: Moscow, ID, USA, 2010. Available online: https://landfire.gov/frcc/frcc_guidebooks.php (accessed on 28 October 2021).

54. LANDFIRE. Vegetation Departure Layer, LANDFIRE 2.0.0; U.S. Department of the Interior, U.S. Geological Survey \& U.S. Department of Agriculture, U.S. Forest Service: Washington, DC, USA, 2021. Available online: http://landfire.cr.usgs.gov/viewer/ (accessed on 23 September 2021).

55. LANDFIRE. Biophysical settings models and descriptions. In LANDFIRE Biophysical Settings Models and Descriptions; [Online]; U.S. Department of Agriculture, U.S. Forest Service \& U.S. Department of the Interior, U.S. Geological Survey, Washington, D.C., and The Nature Conservancy: Arlington, VA, USA, 2020. Available online: https://landfire.gov/bps-models.php (accessed on 1 October 2020).

56. LANDFIRE. Biophysical Setting Layer, LANDFIRE 2.0.0; U.S. Department of the Interior, U.S. Geological Survey \& U.S. Department of Agriculture, U.S. Forest Service: Washington, DC, USA, 2021. Available online: http://landfire.cr.usgs.gov/viewer/ (accessed on 23 November 2020). 
57. LANDFIRE. Succession Classes Layer, LANDFIRE 2.0.0; U.S. Department of the Interior, U.S. Geological Survey \& U.S. Department of Agriculture, U.S. Forest Service: Washington, DC, USA, 2021. Available online: http:/ /landfire.cr.usgs.gov/viewer/ (accessed on 20 November 2020).

58. Homer, C.G.; Dewitz, J.A.; Yang, L.; Jin, S.; Danielson, P.; Xian, G.; Coulston, J.; Herold, N.D.; Wickham, J.D.; Megown, K. Completion of the 2011 National Land Cover Database for the conterminous United States-Representing a decade of land cover change information. Photogramm. Eng. Remote Sens. 2015, 81, 345-354.

59. Hengl, T.; Walsh, M.G.; Sanderman, J.; Wheeler, I.; Harrison, S.P.; Prentice, I.C. Global mapping of potential natural vegetation: An assessment of machine learning algorithms for estimating land potential. PeerJ 2018, 6, e5457. [CrossRef]

60. Provencher, L.; Badik, K.; Anderson, T.; Tuhy, J.; Fletcher, D.; York, E.; Byer, S. Landscape conservation forecasting for data-poor at-risk species on western public lands, United States. Climate 2021, 9, 79. [CrossRef]

61. Potapov, P.; Li, X.; Hernandez-Serna, A.; Tyukavina, A.; Hansen, M.C.; Kommareddy, A.; Pickens, A.; Turubanova, S.; Tang, H.; Silva, C.E.; et al. Mapping global forest canopy height through integration of GEDI and Landsat data. Remote Sens. Environ. 2021, 253, 112165. [CrossRef]

62. Sexton, J.O.; Song, X.-P.; Feng, M.; Noojipady, P.; Anand, A.; Huang, C.; Kim, D.-H.; Collins, K.M.; Channan, S.; DiMiceli, C.; et al. Global, 30-m resolution continuous fields of tree cover: Landsat-based rescaling of MODIS vegetation continuous fields with lidar-based estimates of error. Int. J. Digit. Earth 2013, 6, 427-448. [CrossRef]

63. Pickett, S.T.A.; Thompson, J.N. Patch dynamics and the design of nature reserves. Biol. Conserv. 1978, 13, 27-37. [CrossRef]

64. Wimberly, M.C.; Spies, T.A.; Long, C.J.; Whitlock, C. Simulating historical variability in the amount of old forests in the Oregon Coast Range. Conserv. Biol. 2000, 14, 167-180. [CrossRef]

65. Karau, E.C.; Keane, R.E. Determining landscape extent for succession and disturbance simulation modeling. Landsc. Ecol. 2007, 22, 993-1006. [CrossRef]

66. Keane, R.E.; Hessburg, P.F.; Landres, P.B.; Swanson, F.J. The use of historical range and variability (HRV) in landscape management. For. Ecol. Manag. 2009, 258, 1025-1037. [CrossRef]

67. LANDFIRE. Biophysical setting, 13022_41_50_51, Laurentian-Acadian Northern Hardwoods Forest—Hemlock. In LANDFIRE Biophysical Settings Models and Descriptions; [Online]; LANDFIRE-U.S. Forest Service, U.S. Geological Survey \& The Nature Conservancy (Producers): Washington, DC, USA, 2020. Available online: https://landfire.gov/bps-models.php (accessed on 1 October 2020).

68. LANDFIRE. Biophysical setting, 11250_6_12_13_15_16_17_18_23_24_25_28, Inter-Mountain Basins Big Sagebrush Steppe. In LANDFIRE Biophysical Settings Models and Descriptions; [Online]; LANDFIRE-U.S. Forest Service, U.S. Geological Survey \& The Nature Conservancy (Producers): Washington, DC, USA, 2020. Available online: https:/ /landfire.gov/bps-models.php (accessed on 17 September 2020).

69. LANDFIRE. Existing Vegetation Type Layer, LANDFIRE 2.0.0; U.S. Department of the Interior, U.S. Geological Survey \& U.S. Department of Agriculture, U.S. Forest Service: Washington, DC, USA, 2021. Available online: http://landfire.cr.usgs.gov/ viewer/ (accessed on 23 September 2021).

70. LANDFIRE. Existing Vegetation Cover Layer, LANDFIRE 2.0.0; U.S. Department of the Interior, U.S. Geological Survey \& U.S. Department of Agriculture, U.S. Forest Service: Washington, DC, USA, 2021. Available online: http://landfire.cr.usgs.gov/ viewer/ (accessed on 23 September 2021).

71. LANDFIRE. Existing Vegetation Height Layer, LANDFIRE 2.0.0; U.S. Department of the Interior, U.S. Geological Survey \& U.S. Department of Agriculture, U.S. Forest Service: Washington, DC, USA, 2021. Available online: http://landfire.cr.usgs.gov/ viewer/ (accessed on 23 September 2021).

72. Center for Resilience Science. Secured Areas Spatial Database (CONUS); The Nature Conservancy: Boston, MA, USA, 2021. Available online: https:/ / tnc.maps.arcgis.com/home/item.html?id=e033e6bf6069459592903a04797b8b07 (accessed on 13 September 2021).

73. Frelich, L.E.; Lorimer, C.G. Natural disturbance regimes in hemlock-hardwood forests of the upper Great Lakes region. Ecol. Monogr. 1991, 61, 145-164. [CrossRef]

74. Hupperts, S.F.; Dickinson, Y.L.; Webster, C.R.; Kern, C.C. Promoting structural and species diversity in Great Lakes northern hardwoods: A conceptual model and its application. Forestry 2019, 92, 16-25. [CrossRef]

75. Whitney, G.G. An ecological history of the Great Lakes forest of Michigan. J. Ecol. 1987, 75, 667-684. [CrossRef]

76. Schulte, L.A.; Mladenoff, D.J.; Crow, T.R.; Merrick, L.C.; Cleland, D.T. Homogenization of northern US Great Lakes forests due to land use. Landsc. Ecol. 2007, 22, 1089-1103. [CrossRef]

77. Knapp, S.P.; Kern, C.C.; Webster, C.R. Harvested opening size affects cohort development and failures in a second-growth northern hardwood forest. For. Ecol. Manag. 2021, 482, 118804. [CrossRef]

78. Schroeder, M.A.; Aldridge, C.L.; Apa, A.D.; Bohne, J.R.; Braun, C.E.; Bunnell, S.D.; Connelly, J.W.; Deibert, P.A.; Gardner, S.C.; Hilliard, M.A.; et al. Distribution of Sage-Grouse in North America. Condor 2004, 106, 363-376. Available online: http: / / www.jstor.org/stable/1370643 (accessed on 29 October 2021). [CrossRef]

79. Miller, R.F.; Eddleman, L. Spatial and Temporal Changes of Sage Grouse Habitat in the Sagebrush Biome. Technical Bulletin 151; Oregon State University, Agricultural Experiment Station: Corvallis, OR, USA, 2001. Available online: https://ir.library.oregonstate.edu/ concern/technical_reports/vx021g30s (accessed on 8 December 2021). 
80. West, N.E. Synecology and disturbance regimes of sagebrush steppe ecosystems. In Proceedings: Sagebrush Steppe Ecosystem Symposium; Entwistle, P.G., DeBolt, A.M., Kaltenecker, J.H., Steenhof, K., Eds.; Bureau of Land Management: Boise, ID, USA, 2000; pp. 15-26. Available online: https://s13.amazonaws.com/sfc-dynamic-content/uploadfiles/152/SSSymp.pdf (accessed on 29 October 2021).

81. Davies, K.W.; Bates, J.D.; Boyd, C.S. Effects of intermediate-term grazing rest on sagebrush communities with depleted understories: Evidence of a threshold. Rangel. Ecol. Manag. 2016, 69, 173-178. [CrossRef]

82. Whisenant, S. Changing fire frequencies on Idaho's Snake River Plains: Ecological and management implications. In Proceedings: Symposium on Cheatgrass Invasion, Shrub Die-off, and other Aspects of Shrub Biology and Management, Las Vegas, NV, USA, 5 April 1989; Gen. Tech. Rep. INT-276; McArthur, E.D., Romney, E.M., Smith, S.D., Tueller, P.T., Eds.; U.S. Department of Agriculture, Forest Service, Intermountain Research Station: Ogden, UT, USA, 1990; pp. 4-10. Available online: https://www.fs.fed.us/rm/pubs_ int/int_gtr276/int_gtr276_004_010.pdf (accessed on 5 October 2021).

83. Brooks, M.L.; D’Antonio, C.M.; Richardson, D.M.; Grace, J.B.; Keeley, J.E.; DiThomaso, J.M.; Hobbs, R.J.; Pellant, M.; Pyke, D. Effects of invasive alien plants on fire regimes. Bioscience 2004, 54, 677-688. [CrossRef]

84. Miller, R.F.; Tausch, R.J.; McArthur, E.D.; Johnson, D.D.; Sanderson, S.C. Age Structure and Expansion of Piñon-Juniper Woodlands: A Regional Perspective in the Intermountain West. Research Paper. RMRS-RP-69; U.S. Department of Agriculture, Forest Service, Rocky Mountain Research Station: Fort Collins, CO, USA, 2008. Available online: https://www.fs.fed.us/rm/pubs/rmrs_rp069.pdf (accessed on 17 September 2021).

85. Forest Stewardship Council-US. FSC-US Forest Management Standard (v1.0) (Complete with FF Indicators and Guidance). Approved by FSC-IC, 8 July 2010. 2010. Available online: https: / / us.fsc.org/preview.fsc-us-forest-management-standard-withfamily-forest-indicators.a-189.pdf (accessed on 26 October 2021).

86. U.S. Forest Service. National Forest System Land Management Planning, 36 CFR Part 219 [2012 Planning Rule]. Federal Register 2012, 77, 21162-21276. Available online: https://www.fs.usda.gov/Internet/FSE_DOCUMENTS/stelprdb5362536.pdf (accessed on 10 October 2021).

87. Safford, H.D.; Wiens, J.A.; Hayward, G.D. The growing importance of the past in managing ecosystems of the future. In Historical Environmental Variation in Conservation and Natural Resource Management; Chapter 24; Wiens, J.A., Hayward, G.D., Safford, H.D., Giffen, C.M., Eds.; John Wiley \& Sons: Oxford, UK, 2012. [CrossRef]

88. Walston, L.J.; Hartmann, H.M. Development of a landscape integrity model framework to support regional conservation planning. PLoS ONE 2018, 13, e0195115. [CrossRef] 